\title{
ЖИТТЯ В ІМ'Я НАУКИ ТА УКРАЇНИ. З НАГОДИ ЮВІЛЕЮ ВІДОМОГО ВЧЕНОГО І ГРОМАДСЬКОГО ДІЯЧА МИХАЙЛА АНТОНОВИЧА АНДРЕЙЧИНА
}

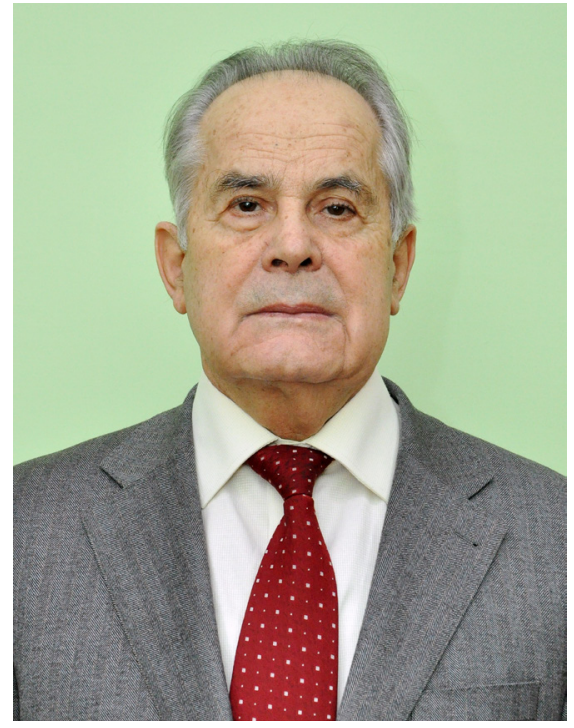

Коротко описано основні біографрічні віхи і творчий доробок Михайла Антоновича Андрейчина - талановитого лікаря, вченого-інфрекціоніста, педагога, громадського діяча, завідувача кафредри інфекційних хвороб з епідеміологією, шкірними і венеричними хворобами Тернопільського національного медичного університету імені І.Я. Горбачевського, академіка НАМН України, доктора медичних наук, профресора, заслуженого діяча науки і техніки України.

22 лютого виповнилося 80 років з дня народження знаного лікаря, вченого-інфекціоніста, педагога, громадського діяча, завідувача кафедри інфекційних хвороб з епідеміологією, шкірними і венеричними хворобами Тернопільського національного медичного університету імені І.Я. Горбачевського, академіка НАМН України, доктора медичних наук, профресора, заслуженого діяча науки і техніки України Михайла Антоновича Андрейчина.

М.А. Андрейчин народився в селянській сім'ї на Тернопільщині. 1957 р. закінчив Копичинецьку середню школу та вступив до Тернопільського державного медичного інституту. Закінчивши інститут з відзнакою, в 1963 р. був зачислений у клінічну ординатуру при кафредрі інфекційних хвороб і епідеміології цього ж інституту. Згодом відслужив дійсну службу в лавах армії, після демобілізації працював терапевтом на Бережанщині. 31969 р. працює на кафедрі іноекційних хвороб та епідеміології Тернопільського медичного інституту, спочатку асистентом, а з 1975 р. - доцентом. У 1970 р. блискуче захистив кандидатську, у 1979 р. - докторську дисертацію на тему «Холемія і бактерійна фрлора в патогенезі та клініці вірусного гепатиту і холециститу» і став на той час наймолодшим в інституті доктором медичних наук. 31981 р. М.А. Андрейчин очолює кафедру інсрекційних хвороб, з 1983 по 2004 рр. - проректор з наукової роботи інституту, а згодом перейменованого в академію, а далі - в університет. У 2007 р. Михайло Антонович обраний членом-кореспондентом, а у 2017 р. - дійсним членом НАМН України.

Палітра наукових інтересів М.А. Андрейчина досить широка. Він не лише активно генерує наукові ідеї, а й наполегливо і послідовно втілює їх у життя. Вагомий внесок зроблено у вивчення нез'ясованих ланок патогенезу вірусних гепатитів, харчової токсикоінфекції, сальмонельозу, шигельозу, оперізувального герпесу, бешихи, еризипелоїду, гострих респіраторних захворювань, лайм-бореліозу і ряду інших інфекційних хвороб. Михайло Антонович описав сім раніше не відомих симптомів (гіпотермія ноги на боці висипу при оперізувальному герпесі поперековокрижової ділянки, дрібні болючі ущільнення в ділянці двоголового м'яза плеча при трихінельозі та ін.). Під керівництвом вченого вперше розроблено термографрічну семіотику розповсюджених інфекційних хвороб, що поглиблює знання про їх патогенез і поліпшує диференційну діагностику.

Важливе значення для розуміння патогенезу вірусних гепатитів мають отримані дані про роль інтерлейкінів, фактора некрозу пухлин-альфа, метаболічної інтоксикації, дисорнкції ендотелію при переході гострої інфекції в хронічну фрорму та розвитку фріброзу печінки, вплив кріоглобулінів різних типів на перебіг хронічного гепатиту $C$ із позапечінковими проявами. Отримано нові дані про особливості біохімічних та імунологічних процесів, розвиток остеопорозу при гепатитах В і C, фрормування фретоплацентарної 
недостатності у вагітних на тлі цих гепатитів та ризик трансплацентарної передачі збудника.

Цінні дослідження проведено з метою з'ясування механізмів лікувальної ефективності різних видів ентеросорбентів при вірусних гепатитах, гострих кишкових інфекціях, лептоспірозі, запропоновано схеми диференційованого призначення їх. Розроблено метод колоносорбції при гострих кишкових інфекціях, що суттєво пришвидшує клінічне одужання хворих на колітні форми цих недуг і забезпечує санацію кишечнику від патогенних мікроорганізмів (без застосування антибіотиків чи хіміопрепаратів). Розроблено аерозольну інтерферонотерапію гострих респіраторних вірусних інсрекцій і доведено її високу клінічну ефективність та економічну перевагу. Отримано й успішно апробовано протилептоспірозний людський імуноглобулін, за допомогою якого вдалось утричі знизити летальність при тяжких формах хвороби. Суттєво поліпшено діагностику і терапію хвороби Лайма.

Вчений узагальнив світовий досвід з медичної протидії біотероризму та обґрунтував необхідність проведення відповідних превентивних заходів в Україні. Здійснив поглиблений аналіз негативного впливу інфекційних хвороб на здоров'я людей і обґрунтував необхідність проведення низки відповідних профрілактичних і лікувальних заходів, спрямованих на поліпшення демографічної ситуації в країні. Долучився до оптимізації навчального процесу на кафедрах інфекційних хвороб і епідеміології медичних університетів України і входження їх в європейський освітній простір. Ювіляр став ініціатором випуску перших навчальних компакт-дисків «Інорекційні хвороби» та «Епідеміологія», співавтором навчальних програм з епідеміології та інфекційних хвороб для вищих навчальних медичних закладів 3-го і 4-го рівнів акредитації.

Науковцям добре відомі численні (понад 1000) наукові, навчально-методичні та публіцистичні праці, написані ним і у співавторстві. Видано понад 50 книг, у т. ч. підручники, навчальні посібники, довідники, керівництва для лікарів, науково-популярні брошури. Має 72 авторських свідоцтва і патенти на винаходи. М. Андрейчин створив школу українських інфекціоністів. Під його керівництвом підготовлено і захищено 17 докторських і 36 кандидатських дисертацій. Учні М. Андрейчина вже очолюють кафедри інсрекційних хвороб у різних університетських містах України (Суми, Чернівці, Сімферополь, Тернопіль, Запоріжжя, Харків).

Більше двадцяти років М.А. Андрейчин як проректор 3 наукової роботи координував науково-дослідну роботу Тернопільського державного медичного інституту, який згодом отримав статус академії та університету. За його сприяння університет увійшов до когорти кращих вищих навчальних медичних закладів України, має потужний науковий потенціал.
Значну увагу М.А. Андрейчин приділяє педагогічній роботі. Його лекціями захоплюються не лише студенти й аспіранти, послухати їх і вчитися лекторської майстерності приходять науковці і практикуючі лікарі. Першочергове значення надає М.А. Андрейчин практичній роботі студентів, оволодінню ними навиками клінічного обстеження хворого, застосуванню найновіших методів діагностики і сучасного лікування, лікарської етики.

У 1994 р. він брав участь у ліквідації спалаху холери на півдні України. Його регулярні клінічні обходи приносять користь не тільки хворим, але й є доброю школою як для молодих, так і для досвідчених лікарів. Примітно, що, побачивши на обході тяжкохворого, Михайло Антонович неодмінно турбується його долею аж до одужання. Так, під час пандемії COVID-19 профресор M.A. Андрейчин щоденно цікавиться станом пацієнтів у Тернопільському інфекційному відділенні, яке виконує роль шпиталю для таких осіб, даючи цінні поради лікарям.

М.А. Андрейчин виконує велику громадську роботу. Ініціатор створення і головний редактор щоквартального всеукраїнського науково-практичного медичного журналу «Інфекційні хвороби» (з 1995 р., вже видано 99 чисел), є членом редакційних колегій і рад 14 медичних журналів України та Польщі.

У 1997 р. очолив ініціативну групу, зусиллям якої було створено Асоціацію інфекціоністів України. Відтоді й дотепер М.А. Андрейчин $є$ незмінним президентом Асоціації. Під його керівництвом уже проведено 5 з'їздів інорекціоністів України, більше 40 пленумів і науково-практичних конференцій, рекомендації яких враховуються Міністерством охорони здоров'я і втілюються у широку медичну практику.

З 2003 р. М.А. Андрейчин очолює Тернопільський осередок Наукового товариства імені Шевченка, з 2007 р. - обраний дійсним членом цього найдавнішого українського наукового товариства. За час головування Михайла Антоновича вже випущено 11 збірників наукових праць осередку та ряд інших видань.

Розробки М.А. Андрейчина, спрямовані на покращання надання медичної допомоги інфекційним хворим, були високо оцінені фрахівцями: удостоєні срібної (1989) і бронзової (1989) медалей на виставках досягнень народного господарства, ряду дипломів. За значні досягнення в галузі інфектології М.А. Андрейчина нагороджено грамотами Верховної Ради України, Почесними грамотами Міністерства охорони здоров'я і Кабінету Міністрів України. У 1998 р. на загальних зборах Академії наук вищої школи України М.А. Андрейчина за створення української школи інсрекціоністів, за внесок у розвиток медичної науки і редагування всеукраїнського науково-практичного медичного журналу «Інфекційні хвороби» було відзначено найпрестижнішою нагородою імені Ярослава Мудрого. Він став лауреатом Всеукраїнської премії ім. С. Подолинського (2005р.), лау- 
реатом премії Національної Академії медичних наук України (2013 р.), премії імені Братів Лепких (2013 р.), нагороджений медаллю Фонду миру, медаллю «Ветеран праці», отримав орден Архистратига Михаїла, орден А. Річинського «За значний внесок у духовність України», медаль «Ветеран праці», медаль Агапіта Печерського Асоціації інсрекціоністів України «За внесок у боротьбу з інсрекційними хворобами», пам'ятну медаль «Знання, душу, серце - людям» (2017р.), орден «За заслуги» третього ступеня (2019р.), є відмінником освіти, відмінником охорони здоров'я.

Протягом ряду років профресор М.А. Андрейчин був експертом ВАК України, членом вченої медичної ради МОЗ України і членом Наукової ради НАМН України. Вже багато років є членом спеціалізованих вчених рад при Інституті епідеміології та інсрекційних хвороб ім. Л.В. Громашевського НАМН України (м. Київ) і Тернопільського національного медичного університету імені І.Я. Горбачевського.

Михайло Антонович - знаний у світі науковець. Його наукові досягнення щодо сучасної терапії гострих і хронічних вірусних гепатитів, лептоспірозу, кишкових інсекцій, доповідалися на численних міжнародних і регіональних з"їздах та конфреренціях. У 1995 р. М.А. Андрейчина обрано дійсним членом Нью-Йоркської академії наук, у 1996 р. - Європейського товариства 3 хіміотерапії інфекційних хвороб, з 1999 р. - він почесний член бібліограсрічного центру Кембриджського університету. Його ім'я і досягнення занесені до авторитетних міжнародних біографічних видань, у тому числі у всесвітній бібліографічний довідник видатних вчених «Who is Who» (1999р.), а також до енциклопедичного словника «Хто $є$ хто в Україні». 32003 р. М.А. Андрейчин є почесним членом Польського товариства лікарів-епідеміологів та інфекціоністів, а з 2005 р. - ще й почесним членом Товариства інфекціоністів Литви.

Багато років тому, довідавшись, що покровителем інфекційних хворих є Святий Рох, якого дуже шанують у християнському світі, Михайло Антонович скрупульозно дослідив долю цієї реально жившої людини і доклав усіх зусиль, аби в 2019 р. перед інфекційним відділенням Тернополя постав величний пам'ятник Святому Роху. Цей монумент має не лише колосальне символічне значення, але й безперечно став окрасою міста. Цікаво, що в дорадянський період скульптури Святого Роха стояли у багатьох поселеннях і, навіть, поблизу школи, в якій починав вчитися майбутній вчений. А наразі це єдиний меморіял цьому святому, споруджений в незалежній Україні.

У 2020 р. Михайло Антонович видав автобіографрічну книгу «Інфекції і люди», в якій доступно й захоплююче описав віражі власної долі, переплетені численними випадками 3 життя лікарської практики і які назавжди закарбувалися у пам'яті автора. Книга стала його своєрідною сповіддю.

Попри велику зайнятість, Михайло Антонович завжди готовий уважно вислухати численних відвідувачів, дати мудру пораду. Він чуйний і простий у спілкуванні. Співробітники, учні поважають його за інтелігентність, порядність і доброзичливість, високий професійний рівень.

Обидва сини - Сергій і Юрій - продовжили лікарську й наукову династію.

Численні колеги та учні, вчителем яких є Михайло Антонович, щиро зичать ювіляру міцного здоров'я, довгих років життя, творчої наснаги і подальших успіхів у нелегкій, але почесній праці науковця, педагога і лікаря.

Колектив Тернопільського національного медичного університету імені І.Я. Горбачевського,

ГО «Всеукраїнська асоціація інфрекціоністів», редакція журналу «Інфрекційні хвороби», друзі, колеги, учні.

\section{THERE IS LIFE IN THE NAME OF SCIENCE AND UKRAINE. ON OCCASION OF ANNIVERSARY OF THE FAMOUS SCIENTIST AND PUBLIC MAN MYKHAYLO ANTONOVYCH ANDREYCHYN}

SUMMARY. Basic biographical milestones and creative achievements of Mykhaylo Antonovych Andreychyn - a prominent physician, infectious scientist, teacher, public figure, head of the Department of Infectious Diseases with Epidemiology, Skin and Venereal Diseases of I. Horbachevsky Ternopil National Medical University, Academician of the National Academy of Medical Sciences of Ukraine, Doctor of Medical Sciences, Professor, Honored Worker of Science and Technology of Ukraine.

Конфрлікт інтересів: немає.

Authors have no conflict of interest to declare.

Отримано 22.02.2020 р. 